\title{
PENGARUH PARAMETER PEMESINAN TERHADAP KEKASARAN PERMUKAAN MATERIAL ALUMINIUM 6061 DAN 7075 PADA PROSES SEKRAP
}

\author{
M. Sobron Y. Lubis ${ }^{1}$, Abrar Riza ${ }^{2}$, Dani Putra Agung ${ }^{3}$ \\ ${ }^{123}$ Program Studi Teknik Mesin, Jurusan Teknologi Industri, Fakultas Teknik Universtias Tarumanagara \\ Emaill: sobronl@ft.untar.ac.id \\ Email3: williamdanny1995@gmail.com
}

Masuk: 10-04-2019, revisi: 11-05-2020, diterima untuk diterbitkan: 11-05-2020

\begin{abstract}
ABSTRAK
Bahan logam aluminium Alloy banyak digunakan dalam pembuatan konstruksi ringan pada mesin-mesin. Untuk menghasilkan permukaan logam alluminium alloy yang rata, maka diperlukan mesin sekrap. Terdapat dua jenis material aluminium yang umum digunakan yaitu Aluminium 6061 dan 7075. Pada proses pembentukan logam dengan menggunakan mesin sekrap, adalah penting untuk menentukan parameter pemesinan Karena hal ini berkaitan erat dengan kondisi permukaan benda kerja yang dihasilkan. Kesulitan dalam menentukan kombinasi parameter pemesinan yang sesuai seringkali mengakibatkan kondisi permukaan benda kerja kerja yang tidak sesuai diharapkan atau memiliki kekasaran yang tinggi. Dengan parameter yang tepat, kualitas kekasaran permukaan dapat diprediksi seperti yang direncanakan sebelum proses pemesinan. Parameter pemotongan tersebut adalah kecepatan pemotongan dan kedalaman potong. Pada penelitian ini kecepatan pemotongan yang digunakan bervariasi yaitu 4,68 $\mathrm{m} / \mathrm{min}, 7,30 \mathrm{~m} / \mathrm{min}, 11,70 \mathrm{~m} / \mathrm{min}, 18,29 \mathrm{~m} / \mathrm{min}$ dengan kedalaman pemotongan $0,50 \mathrm{~mm}, 1,00 \mathrm{~mm}$ dan 1,50 mm, untuk memotong aluminum 6061 dan 7075 dengan menggunakan mata pahat HSS.. Pada langkah awali dilakukan setting mesin perkakas, meletakkan mata pahat pada pemegang mata pahat, meletakkan benda kerja pada ragum, melakukan settingg untuk kecepatan pemotongan, kedalaman pemakanan, dan melakukan pemesinan. Setiap kali selesai pemesinan, dilakukan pengukuran kekasaran permukaan dengan menggunakan alat ukur surface test. Dari hasil penelitian diperoleh bahwa nilai kekasaran permukaan berbanding lurus dengan kedalaman potong. Nilai kekasaran permukaan berbanding terbalik dengan kecepatan potong dan kekerasan material. Penentuan kecepatan potong melalui persamaan empiris berdasarkan kekasaran permukaan: aluminium alloy 6061 adalah: $\mathrm{Ra}=$ 23.366e-0.146Vc $(\mu \mathrm{m})$ dan aluminium alloy 7075 adalah: $\mathrm{Ra}=13.482 \mathrm{e}-0.109 \mathrm{Vc}(\mu \mathrm{m})$.
\end{abstract}

Kata Kunci: Kecepatan potong; kedalaman potong; kekasaran permukaan; parameter pemesinan

\begin{abstract}
Aluminum Alloy metal is widely used in making lightweight construction on machinery. To produce a flat metal alluminium alloy surface, a shearing machine is needed. There are two types of aluminum materials that are commonly used, namely Aluminum 6061 and 7075. In the process of forming metals using a scrap machine, it is important to determine the machining parameters because this is closely related to the surface conditions of the workpiece produced. Difficulties in determining the appropriate combination of machining parameters often result in work surface conditions that are not as expected or have a high roughness. With the right parameters, the quality of surface roughness can be predicted as planned before the machining process. The cutting parameters are cutting speed and cutting depth. In this study the cutting speed used varied, namely $4.68 \mathrm{~m} / \mathrm{min}, 7.30 \mathrm{~m} / \mathrm{min}, 11.70 \mathrm{~m} /$ min, $18.29 \mathrm{~m} / \mathrm{min}$ with a cutting depth of $0.50 \mathrm{~mm}, 1.00 \mathrm{~mm}$ and $1,50 \mathrm{~mm}$, to cut aluminum 6061 and 7075 using the HSS chisel. In the initial step, do the machine tool settings, place the chisel on the chisel holder, place the workpiece in vise, adjust the cutting speed, depth of feed, and perform machining. After machining, a surface roughness measurement is carried out using a surface test. From the results of the study it was found that the value of surface roughness is directly proportional to the depth of cut. The value of surface roughness is inversely proportional to cutting speed and hardness of the material. Determination of cutting speed through empirical equations based on surface roughness: aluminum alloy 6061 is: $R a=23,366 e-0,146 V c$ ( $\mu m$ ) and aluminum alloy 7075 are: $R a=13,482 e-0.109 \mathrm{Vc}(\mu \mathrm{m})$.
\end{abstract}

Keywords: Cutting speed; depth of cut; surface roughness; machining parameters 


\section{PENDAHULUAN}

Mesin sekrap digunakan untuk pengerjaan permukaan meliputi bidang-bidang datar, bidang menyiku saling tegak lurus, bidang alur buntu dan tembus, bidang bertingkat, dan bidang bersudut. Proses pemotongannya menggunakan suatu gerak bolak-balik yang menghasilkan pemotongan linier sesuai panjang langkah (Taufiq, 1993). Dalam proses sekrap tentunya diinginkan hasil permukaan yang rata dan kekasaran permukaan yang baik sesuai yang direncanakan. Penentuan kekasaran permukaan yang baik dapat dipengaruhi oleh sudut pisau dan juga penggunaan parameter pemesinan. Pada proses pemesinan sekrap, parameter pemesinan memiliki peran penting dalam menciptakan kualitas kekasaran permukaan. Banyak faktor dari parameter pemesinan yang mempengaruhi kualitas produk yang dihasilkan, seperti kecepatan potong, kedalaman potong, dan sudut pemakanan. Dengan mengetahui variasi parameter pemesinan yang tepat, kualitas kekasaran permukaan bisa dihasilkan dengan optimal.(Rao, 2003). Bahan allumium 6061 umumnya digunakan pada otomotive seperti car wheels, struktur dan panel, piston, brake disc, brake drum. Sedangkan bahan aluminium 7075 umumnya digunakan pada structure aircraft, fitting gears dan shafts (Santos, 2016).

Pada proses milling bahan Titanium Alloy Ti 1023, kekasaran permukaan benda kerja bertambah bilamana kecepatan pemotongan meningkat dari $40 \mathrm{~s} / \mathrm{d} 100 \mathrm{~m} / \mathrm{min}$, dan kekasaran permukaan berkurang apabila kecepatan pemotongan bertambah dari 100 sd $300 \mathrm{~m} / \mathrm{min}$ dengan menggunakan pahat baru. (Houchuan, 2015).

Faktor-faktor yang mempengaruhi kualitas permukaan suatu benda kerja pada proses pemesinan diantaranya adalah sudut dan ketajaman pisau potong dalam proses pembuatannya, variasi kecepatan potong, posisi senter, getaran mesin, perlakuan panas yang kurang baik dan sebagainya. Parameter yang sangat menentukan kekasaran permukaan adalah kedalaman pemotongan (depth of cut), laju pemakanan (feed rate) dan kecepatan potong (Kalpakjian, 2003). Permasalahannya adalah bagaimana menentukan kombinasi parameter pemesinan yang sesuai. Oleh karena itu, penelitian ini dilakukan dengan tujuan untuk mengetahui pengaruh parameter pemesinan terhadap kekasaran permukaan material aluminium 6061 dan alluminium 7075.

\section{METODE PENELITIAN}

Penelitian ini dilakukan secara eksperimental. Mata pahat HSS melakukan pengerjaan pemotongan Bahan Aluminium 6061 dan 7075 dengan beberapa variasi parameter pemesinan yaitu sebanyak 3 variasi kedalaman makan dan 4 variasi kecepatan potong. Benda kerja hasil proses pemotongan kemudian dilakukan uji kekasaran permukaan benda kerja dengan menggunakan surface tester.

Peralatan dan bahan yang digunakan antara lain:

a. Mesin Sekrap

b. Mata Potong HSS dengan Nose Radius $10 \mathrm{~mm}$

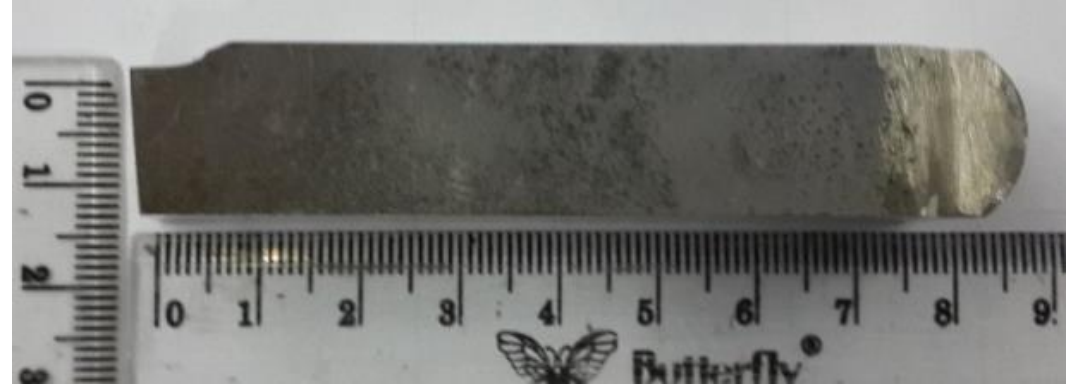

Gambar 1. Mata Potong HSS (sumber: dokumentasi Dani, 2019) 
c. Aluminium Alloy 6061 dan 7075 dengan dimensi 50 x 25 x100 mm
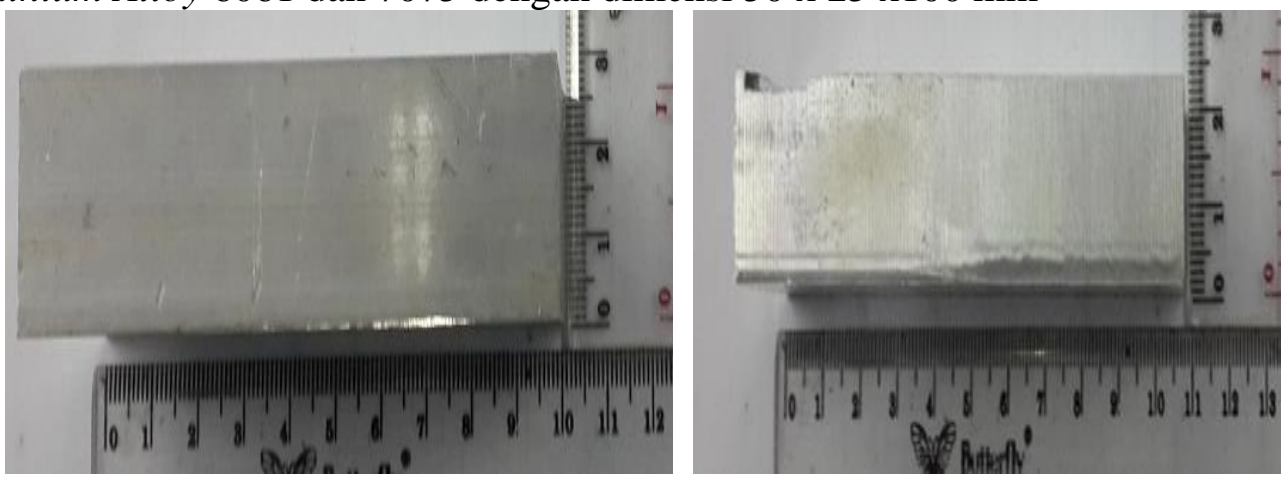

Gambar 2. Aluminium Alloy 6061(sumber: dokumentasi Dani, 2019)

d. Surface Tester Mitutoyo MST-211

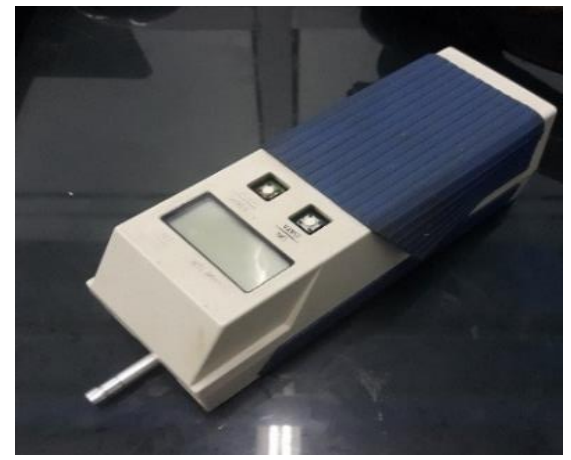

Gambar 3. Suface Tester(sumber: dokumentasi Dani, 2019)

Perhitungan kecepatan potong diperoleh dengan menggunakan persamaan berikut: (Hassan, 2014)

$$
V c=\frac{\mathrm{np} \cdot \mathrm{lt}(1+\mathrm{Rs})}{2.1000}
$$

Dengan diketahui jumlah langkah pemakanan $\left(\mathrm{n}_{\mathrm{p}}\right)$ menggunakan persamaan diatas, kemudian dilakukan pengukuran terhadap panjang langkah gerak makan total mesin sekrap $\left(l_{t}\right)$ dengan cara mengukur perpindahan jarak mata potong dari titik awal hingga kembali ke titik awal. Kemudian jangka waktu pergerakan maju dan mundur mesin sekrap diukur menggunakan stopwatch untuk mendapatkan nilai perbandingan waktu $\left(\mathrm{R}_{\mathrm{s}}\right)$ antara waktu yang dibutuhkan mesin untuk maju dan untuk mundur. Setiap kali selesai melakukan pengujian, permukaan benda kerja diukur kekasaran menggunakan surface tester. Pengambilan data menggunakan kelas kekasaran permukaan N6 yang memiliki panjang sampel 0,8 mm (Black, 2008). Variasi parameter pemotongan ditunjukkan pada Tabel 2.

Tabel 1. Variasi parameter pemotongan

\begin{tabular}{|c|c|c|c|c|c|}
\hline \multicolumn{2}{|c|}{$\begin{array}{l}\text { Jenis Mesin : } \\
\text { Mesin Shaping Sekrap } \\
\text { Parameter Pemesinan : } \\
\text { Feeding : } 0.7 \mathrm{~mm}\end{array}$} & \multicolumn{4}{|c|}{$\begin{array}{l}\text { Aluminium Alloy } 6061 \text { dan } 7075 \\
\text { Dimensi : } \mathrm{p} \times 1 \times \mathrm{t}=100 \times 25 \times 50 \mathrm{~mm}\end{array}$} \\
\hline No. & Keterangan & 1 & 2 & 3 & 4 \\
\hline 1 & Cutting Speed & $4,68 \mathrm{~m} / \mathrm{min}$ & $7,30 \mathrm{~m} / \mathrm{min}$ & $11,70 \mathrm{~m} / \mathrm{min}$ & $18,29 \mathrm{~m} / \mathrm{min}$ \\
\hline 2 & Depth of Cut & $0,50 \mathrm{~mm}$ & $1,00 \mathrm{~mm}$ & $1,50 \mathrm{~mm}$ & \\
\hline 3 & Jenis Mata Potong & \multicolumn{4}{|c|}{$H S S(\mathrm{r}=10 \mathrm{~mm})$} \\
\hline
\end{tabular}


Pada perhitungan kekasaran permukaan, bentuk mata pahat dan feed rate yang dimiliki oleh mata potong memiliki pengaruh terhadap hasil ketinggian permukaan benda kerja pada proses pemesinan (Black, 2008). Nilai kekasaran permukaan secara teoritis dapat dicari menggunakan persamaan (2) setelah ketinggian maksimum ketidakrataan diperoleh. Ketinggian maksimum ketidakrataan diperoleh menggunakan perhitungan trigonometri sesuai bentuk dari geometri permukaan benda kerja yang dipengaruhi oleh nose radius mata pahat dan feed rate yang diberikan. Dapat digambarkan pendekatan geometri permukaan benda kerja terhadap posisi nose radius dan feed rate seperti gambar 4 berikut.

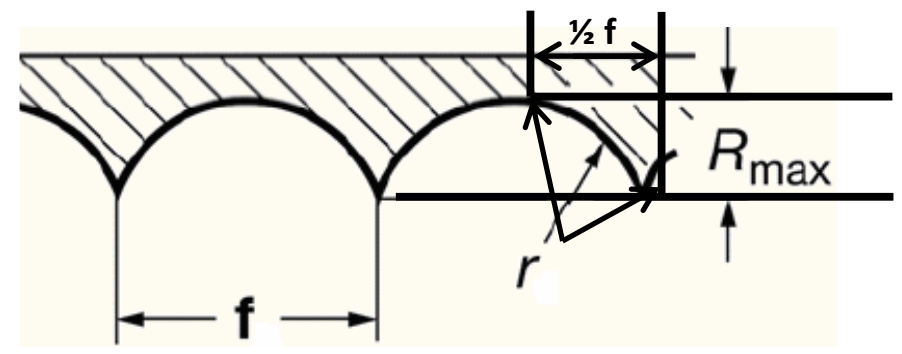

Gambar 4. Geometri Nose Radius Mata Potong[8]

Hasil penurunan rumus ketinggian maksimum ketidakrataan menggunakan teori trigonometri dari segitiga siku-siku antara $\mathrm{R}_{\max }, \mathrm{f}$, dan juga $\mathrm{r}$ adalah:

$$
R_{\max }=\frac{r-\sqrt{r^{2}-\left(f^{f} / 2\right)^{2}}}{\sin 90}
$$

Setelah melakukan perhitungan dengan menggunakan persamaan (2), didapatkan hasil nilai $\mathrm{R}_{\max }$ sebesar 7,6 $\mu \mathrm{m}$. kemudian dilanjutkan ke persamaan (3) yaitu: [8]

$$
R_{\mathrm{a}}=\frac{\mathrm{Rmax}}{4}
$$

Keterangan :

$\mathrm{R}_{\mathrm{a}} \quad=$ Kekasaran Permukaan

$\mathrm{R}_{\max } \quad=$ Ketinggian Maksimal Ketidakrataan Permukaan

Nilai $\mathrm{R}_{\max }$ merupakan kesamaan dari kedalaman potong $(a)$

Maka secara teoritis didapatkan nilai $\mathrm{R}_{\mathrm{a}}$ yang konstan sebesar $1,915 \mu \mathrm{m}$. Terdapat sebuah persamaan yang dapat digunakan untuk menentukan kekasaran permukaan berdasarkan kedalaman potong dan kekerasan permukaan yaitu: (Halevi, 1995).

$$
R_{\mathrm{a}}=\frac{a \cdot B H N^{0.8}}{32}
$$

Dengan:

$R_{\mathrm{a}} \quad=$ Kekasaran Permukaan $(\mu \mathrm{m})$

BHN $=$ Kekerasan Permukaan $\left(\mathrm{kg} / \mathrm{mm}^{2}\right)$

$a \quad=$ Kedalaman Potong $(\mathrm{mm})$

Dengan persamaan menggunakan persamaan (4), maka didapatkan rata-rata nilai setiap kekasaran permukaan dengan setiap variasi kedalaman makan dan kekerasan material berikut.

Tabel 2. Nilai Kekasaran Terhadap Kekerasan Material dan Kedalaman Potong

\begin{tabular}{cccc}
\multicolumn{2}{c}{} & \multicolumn{3}{c}{$\mathrm{R}_{\mathrm{a}}(\mu \mathrm{m})$} \\
\hline Material & & $\mathrm{A} 17075$ & $\mathrm{Al} \mathrm{6061}$ \\
\hline \multirow{3}{*}{$a(\mathrm{~mm})$} & 0,50 & 0,86 & 0,60 \\
\cline { 2 - 4 } & 1,00 & 1,72 & 1,19 \\
\cline { 2 - 4 } & 1,50 & 2,58 & 1,79 \\
\hline
\end{tabular}


Setelah seluruh variasi parameter pemesinan selesai diuji, diambil nilai kekasaran yang terkecil dari antara 2 material tersebut, kemudian dilakukan perbandingan secara teoritis, sehingga didapatkan persamaan yang melibatkan pengaruh kecepatan potong dan kedalaman makan dalam hasil kekasaran permukaan pada proses sekrap.

\section{HASIL DAN PEMBAHASAN}

Setelah dilakukan proses pemesinan permukaan benda kerja dilakukan untuk menghasilkan permukaan benda kerja yang rata, kemudia dilakukan pengukuran kekasaran permukaan benda kerja tersebut dengan menggunakan alat ukur surface test. Hal ini untuk mengetahui pengaruh kecepatan potong dan kedalaman potong terhadap nilai kekasaran permukaan yang dihasilkan dari proses pemesinan tersebut. Hasil pengukuran kekasaran permukaan benda kerja material aluminium alloy 6061 pada Tabel.3

Tabel 3. Nilai Hasil Kekasaran Permukaan untuk Material Al 6061

\begin{tabular}{|c|c|c|c|}
\hline \multirow{5}{*}{$\begin{array}{c}\text { Kecepatan } \\
\text { Potong Per } \\
\text { menit }(\mathrm{mm} / \mathrm{min})\end{array}$} & \multicolumn{3}{|c|}{ Material Benda Kerja : Al 6061} \\
\hline & Jenis Mata Pahat & \multicolumn{2}{|l|}{ : HSS } \\
\hline & Feeding & \multicolumn{2}{|c|}{ : $0,7 \mathrm{~mm} /$ langkah } \\
\hline & \multicolumn{3}{|c|}{ Nilai Kekasaran Permukaan $\mathrm{Ra}(\mu \mathrm{m})$} \\
\hline & $\mathrm{a}_{1}(\mathrm{~mm})$ & $\mathrm{a}_{2}(\mathrm{~mm})$ & $\mathrm{a}_{3}(\mathrm{~mm})$ \\
\hline $\mathrm{Vc}_{1}$ & 7.65 & 20.00 & 21.28 \\
\hline $\mathrm{Vc}_{2}$ & 15.86 & 17.69 & 18.46 \\
\hline $\mathrm{Vc}_{3}$ & 14.46 & 15.10 & 15.72 \\
\hline $\mathrm{Vc}_{4}$ & 11.63 & 12.96 & 14.22 \\
\hline
\end{tabular}

Berdasarkan Tabel 3 dapat diketahui bahwa peningkatan kecepatan pemotongan, memberi efek terhadap peningkatan nilai kekasaran permukaan benda kerja. Sedangkan peningkatan penggunaan kedalaman potong memberi efek terhadap penurunan nilai kekasaran permukaan dalam hal ini kondisi permukaan benda kerja lebih licin.

Sedangkan nilai hasil pengukuran kekasaran permukaan benda kerja aluminium alloy 7075 dapat dilihat pada Tabel.4.

Tabel 4. Nilai Hasil Kekasaran Permukaan untuk Material Al 7075

\begin{tabular}{cccc}
\hline & \multicolumn{3}{l}{ Material Benda Kerja : Al 7075 } \\
Kecepatan & Jenis Mata Pahat & $:$ HSS \\
Potong Per & Feeding & $: 0,7$ mm/langkah \\
\cline { 2 - 4 } menit $(\mathrm{mm} / \mathrm{min})$ & \multicolumn{3}{c}{ Nilai Kekasaran Permukaan $\mathrm{R}_{\mathrm{a}}(\mu \mathrm{m})$} \\
\cline { 2 - 4 } & $a_{1}(\mathrm{~mm})$ & $a_{2}(\mathrm{~mm})$ & $a_{3}(\mathrm{~mm})$ \\
\hline $\mathrm{Vc}_{1}$ & 10.96 & 11.39 & 13.43 \\
\hline $\mathrm{Vc}_{2}$ & 10.36 & 10.73 & 12.36 \\
\hline $\mathrm{Vc}_{3}$ & 8.62 & 10.08 & 11.68 \\
\hline $\mathrm{Vc}_{4}$ & 8.09 & 8.19 & 8.99 \\
\hline
\end{tabular}


Berdasarkan Tabel 4 dapat diketahui bahwa peningkatan kecepatan pemotongan, memberi efek terhadap peningkatan nilai kekasaran permukaan benda kerja. Sedangkan peningkatan penggunaan kedalaman potong memberi efek terhadap penurunan nilai kekasaran permukaan.

Perbandingan kedalaman pemotongan dan kecepatan pemotongan terhadap nilai kekasaran permukaan benda kerja aluminium Al 6061 disampaikan pada Gambar 5

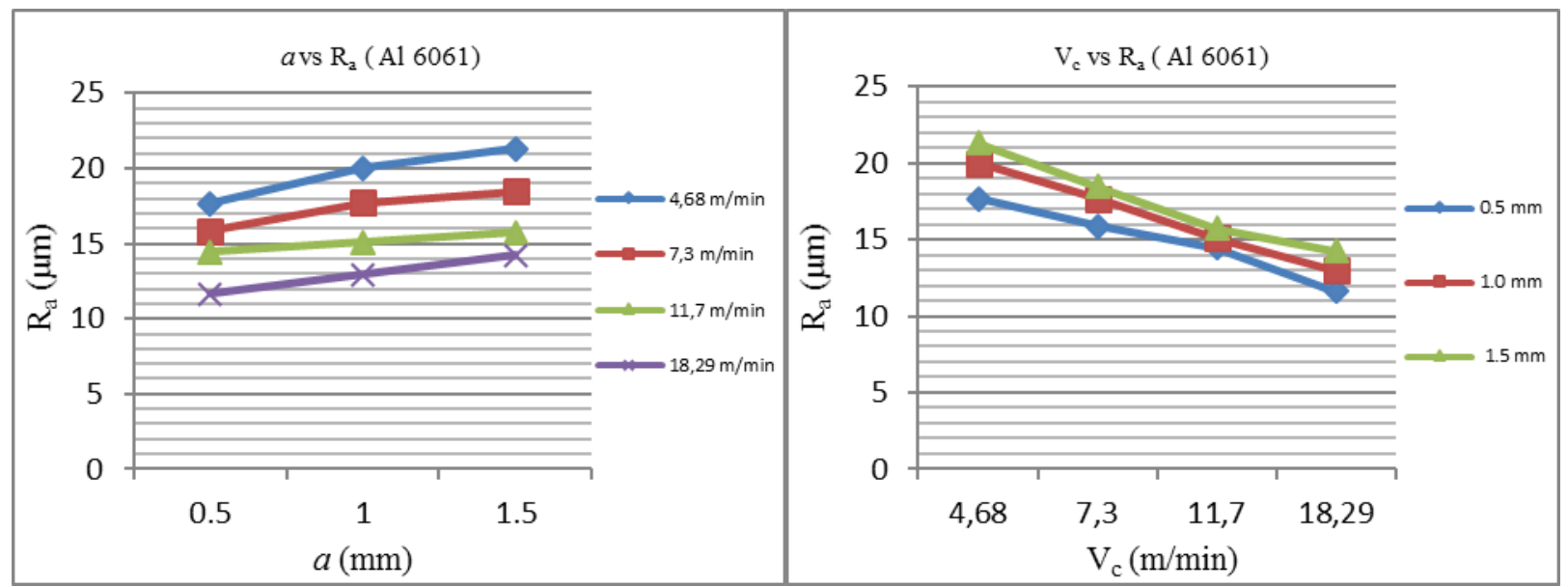

Gambar 5. Pengaruh Kedalaman Potong dan Kecepatan Potong Terhadap Kekasaran Permukaan Material Al 6061

Gambar 5. menunjukkan peningkatan nilai $\mathrm{R}_{\mathrm{a}}$ yang konsisten ketika nilai kedalaman potong dinaikkan. Sementara itu nilai $\mathrm{R}_{\mathrm{a}}$ rata-rata mengalami penurunan pada setiap peningkatan kecepatan potong yang sama dengan peningkatan kecepatan putaran mata potong.

Perbandingan kedalaman pemotongan dan kecepatan pemotongan terhadap nilai kekasaran permukaan benda kerja aluminium Al 7075 disampaikan pada Gambar 6

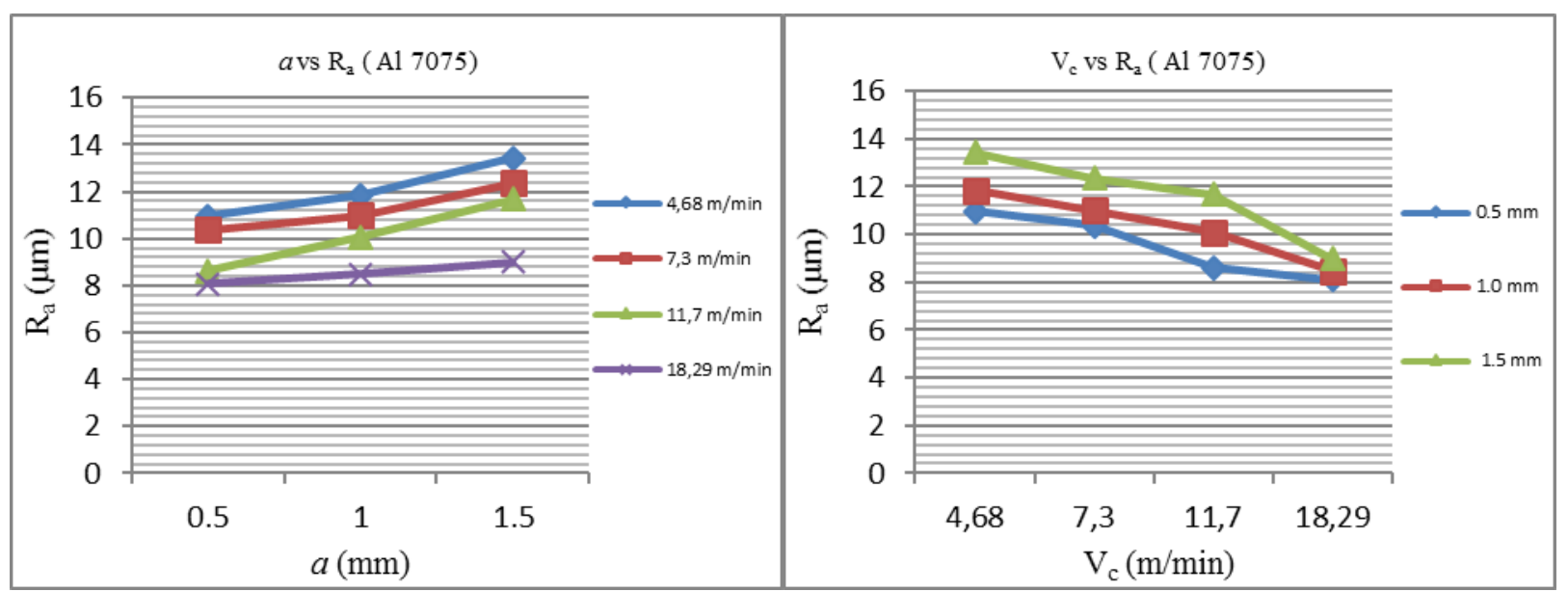

Gambar 6. Pengaruh Kedalaman Potong dan Kecepatan Potong Terhadap Kekasaran Permukaan Material Al 7075

Gambar 6. menunjukkan penurunan nilai kekasaran permukaan berbanding lurus dengan kenaikan kecepatan potong. Kecepatan potong yang semakin tinggi menghasilkan kualitas permukaan yang lebih baik, dan nilai kedalaman mpotong yang semakin rendah menghasilkan kualitas permukaan yang lebih baik juga. 
Dalam penelitian ini, kecepatan potong dianalisis berdasarkan data yang didapatkan. Kemudian sebuah persamaan matematis ditentukan berdasarkan trendline terbaik yang didapatkan.

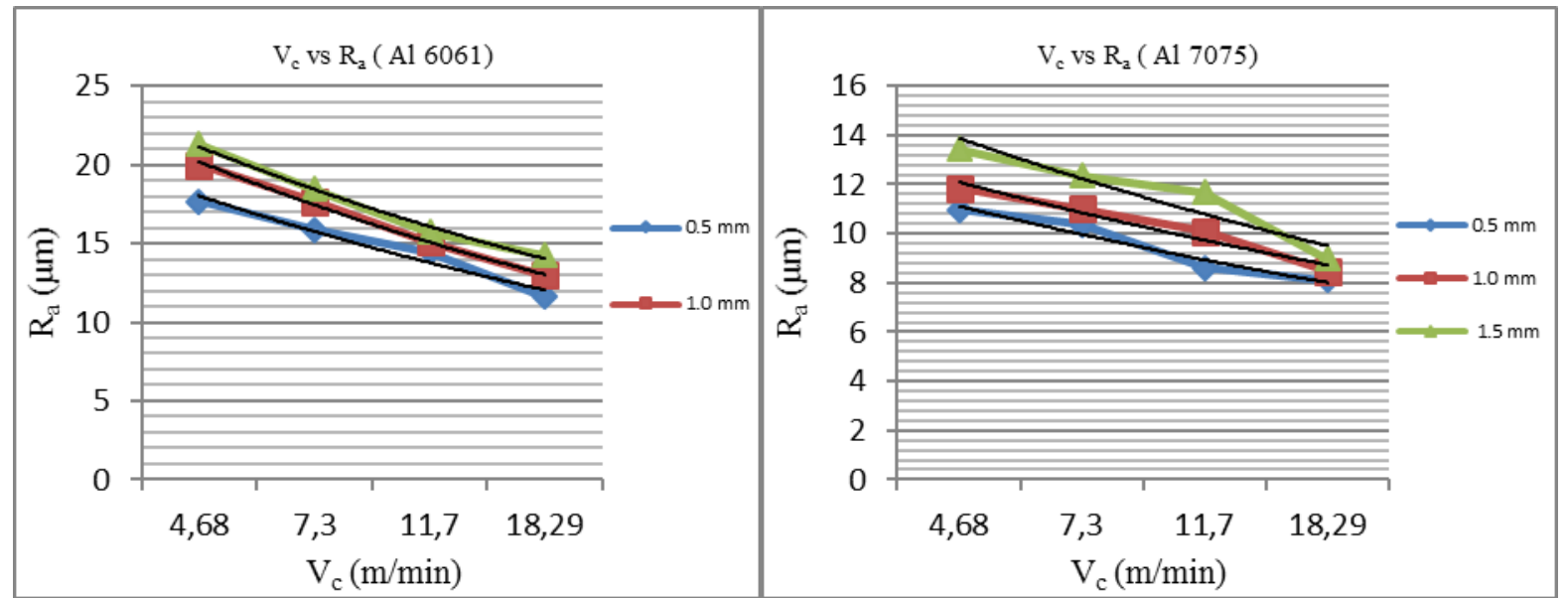

Gambar 7. Trendline Pengaruh Kecepatan Potong Terhadap Kekasaran Permukaan Material Al 6061 dan Al 7075

Untuk mengetahui trendline dari data hasil pengukuran yang dilakukan dari kedua jenis benda kerja yang digunakan, maka dilakukan perhitungan dengan menggunakan persamaan sehingga diperoleh persamaan trendline untuk kedua jenis material tersebut dengan kecepatan potong yang bervarias dan menjadi rujukan dalam menentukan nilai kekasaran permukaan,dari grafik di atas adalah sebagaimana diuraikan pada Tabel 5.

Tabel 5. Nilai Trendline untuk Material Al 6061 dan Al 7075

\begin{tabular}{cclc}
\hline Material & Kedalaman Potong $(\mathrm{mm})$ & Persamaan & $\mathrm{R}^{2}$ \\
\hline \multirow{3}{*}{ Al 6061 } & 0.5 & $\mathrm{y}=20.611 \mathrm{e}^{-0.134 \mathrm{x}}$ & 0.9571 \\
\cline { 2 - 4 } & 1.0 & $\mathrm{y}=23.366 \mathrm{e}^{-0.146 \mathrm{x}}$ & 0.9971 \\
\cline { 2 - 4 } A1 7075 & 1.5 & $\mathrm{y}=24.246 \mathrm{e}^{-0.137 \mathrm{x}}$ & 0.9921 \\
\cline { 2 - 4 } & 0.5 & $\mathrm{y}=12.403 \mathrm{e}^{-0.109 \mathrm{x}}$ & 0.9510 \\
\cline { 2 - 4 } & 1.0 & $\mathrm{y}=13.482 \mathrm{e}^{-0.109 \mathrm{x}}$ & 0.9579 \\
\hline
\end{tabular}

Perbandingan nilai kekasaran permukaan yang dihasilkan antara kedua jenis material ditunjukkan pada Gambar 8.

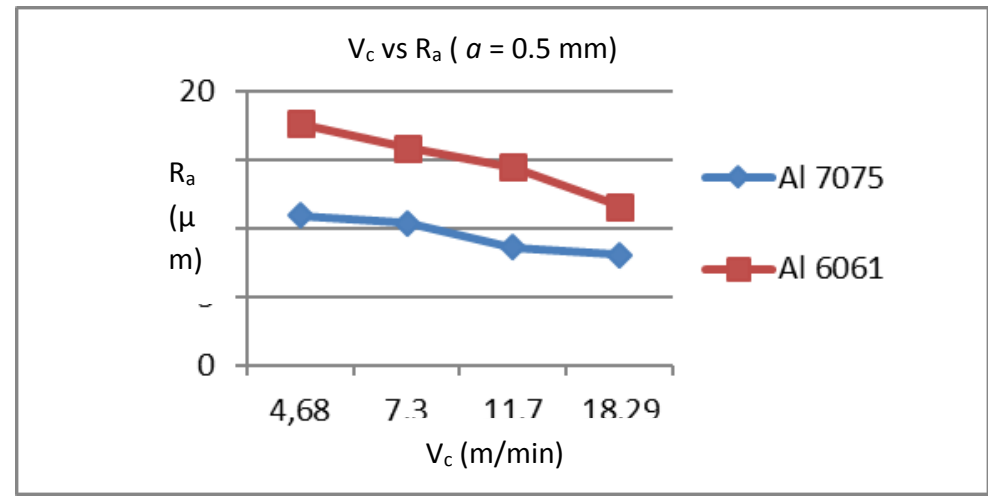

Gambar 8. Perbandingan Kecepatan Potong Terhadap Kekasaran Permukaan Antara Material Aluminium 6061 dan 7075 
Berdasarkan Gambar 8. dapat dilihat bahwa nilai kekasaran permukaan antara material Al 6061 dan Al 7075 memiliki selisih yang cukup besar. Salah satu perbedaan pada kedua jenis aluminium ini disebabkan oleh nilai kekerasan material yang dimiliki. Kekerasan pada material Al 6061 sebesar 95 BHN, sedangkan material Al 7075 sebesar 150 BHN (Sandvick, 2015). Dan perbedaan kedalaman potong pada mesin sekrap juga memiliki pengaruh terhadap kualitas permukaan yang dihasilkan dari proses pemesinan. Sehingga, kedua hal ini tentu memiliki pengaruh yang harus diperhitungkan untuk menghasilkan kualitas permukaan yang optimal. Dari hasil diatas didapatkan bahwa perubahan nilai kedalaman potong $(a)$ berbanding lurus dengan kekasaran permukaan. Semakin besar kedalaman potong yang digunakan pada proses pemesinan, maka nilai kekasaran permukaan benda kerja yang dihasilkan semakin besar. Sedangkan pada perubahan nilai kekerasan benda kerja $(\mathrm{BHN})$ berbanding terbalik dengan nilai kekasaran permukaan $\left(\mathrm{R}_{\mathrm{a}}\right)$. Semakin besar nilai $\mathrm{BHN}$, maka nilai $\mathrm{R}_{\mathrm{a}}$ yang didapatkan akan semakin kecil. Hal ini mendukung hasil kajian yang diperoleh oleh Wardaya dkk (2012) mengatakan bahwa semakin kecil kekerasan bahan yang digunakan untuk proses pemesinan maka nilai kekasaran permukaan yang didapatkan juga semakin kecil. Hal ini diakibatkan karena pada material yang semakin lunak akan terjadi proses burr, dimana sebagian dari material dari proses pemotongan masih melekat pada benda kerja dan tidak terlepas dengan sempurna sehingga permukaan lebih kasar dibandingkan material yang mempunyai tingkat kekerasan yang lebih tinggi (Malik, 2018).

\section{KESIMPULAN DAN SARAN}

\section{Kesimpulan}

Dari hasil penelitian maka diperoleh kesimpulan sebagai berikut :

a. Nilai kekasaran permukaan berbanding lurus dengan kedalaman potong. Nilai kedalaman potong yang semakin besar menghasilkan nilai kekasaran permukaan yang semakin besar.

b. Nilai kekasaran permukaan berbanding terbalik dengan kecepatan potong dan kekerasan material. Kecepatan potong dan nilai kekerasan material yang semakin tinggi menghasilkan nilai kekasaran permukaan yang semakin rendah.

c. Persamaan empiris untuk menentukan kecepatan potong berdasarkan kekasaran permukaan:

$$
\begin{array}{ll}
\text { Aluminium Alloy 6061: } & \mathrm{Ra}=23.366 \mathrm{e}^{-0.146} \mathrm{Vc}(\mu \mathrm{m}) \\
\text { Aluminium Alloy 7075: } & \mathrm{Ra}=13.482 \mathrm{e}^{-0.109} \mathrm{Vc}(\mu \mathrm{m})
\end{array}
$$

\section{Saran}

Terdapat beberapa saran yang dapat dimanfaatkan untuk melakukan penelitian lebih lanjut yaitu sebagai berikut:

a. Penelitian menggunakan rumus di atas dengan range parameter pemotongan yang lebih luas dan menggunakan tool dengan spesifikasi berbeda pada material aluminium alloy Al-6061 dan Al-7075.

b. Penelitian untuk mengetahui korelasi langsung antara kedalaman potong, kecepatan potong, dan kekerasan material terhadap kekasaran permukaan pada material aluminium alloy Al6061 dan Al-7075 


\section{REFERENSI}

Black, J. and Kohser, R., A. (2008). De Garmo's Materials and Process in Manufacturing, John Wiley \& Sons, Inc. New Jersey.

Halevi, G., and Weill, D.R. (1995).Principle of Process and Planning a Logical Approach. Published by Chapman \& Hall. 26 Boundary Row London SEI 8 HN, UK

Hassan, A.. Fundamentals of Machining Processes. (2014). Conventinal and Nonconventional Processes. CRC-Press. New York.

Houchuan, Y., Zhitong, C., \& ZiTong, Z. (2015). Influence of Cutting Speed and Tool Wear on the Surface Integrity of the Titanium Alloy Ti-1023 During Milling. The International Journal of Advanced Manufacturing Technology, 78(5-8), 1113-1126.

Kalpakjian, S. and Steven, R. S. (2003). Manufacturing Process for Engineering Material. $4^{\text {th }}$ Edition.Prentice-Hall, 2003. New Jersey.

Malik, A. K., dan Gorana. V. K. (2018). Tool Forces Dynamometer for Shaper Machine. International Journal on Future Revolution in Computer Science \& Communication Engineering ISSN: 2454-4248 Volume: 4 Issue: 1

Rao, P. (2003). Manufacturing Technology Metal Cutting and Machine Tools Volume 2. Tata Mc Graw Hill Publishing Company Limited. New Delhi.

Sandvick Catalog 2015.

Santos, M. C., Machado, A. R., Sales, W. F., Barrozo, M. A., \& Ezugwu, E. O. (2016). Machining of Aluminum Alloys: a Review. The International Journal of Advanced Manufacturing Technology, 86(9-12), 3067-3080.

Taufiq, R. (1993).Teori Dan Teknologi Proses Pemesinan, Penerbit: Institut Teknologi Bandung: Bandung

Wardaya, S. S, HS Asep, dan TR Rifky.(2012).Pengaruh Kekerasan Bahan dan Feeding Terhadap Kekasaran Permukaan Hasil Penyayatan Pisau Frais”, TORSI, vol. 10, no. 2, pp. 197-206 
